\title{
CHARACTERIZATION AND SENSITIVITY TEST OF THE ALLERGENIC POLLEN PROTEINS FROM LITCHI CHIMENSIS PLANT
}

\author{
${ }^{1}$ RANAJIT KUMAR SHAHA, ${ }^{2}$ NITAI ROY AND ${ }^{2}$ G. TALUKDAR \\ ${ }^{1}$ Faculty of Agro Based Industry. Universiti Malaysia Kelantan, Jeli Campus, Kelantan, Malaysia \\ ${ }^{2}$ Department of Biochemistry \& Molecular Biology, University of Rajshahi, Rajshahi-6205, Bangladesh
}

Corresponding author: ranajit@umk.edu.my

\begin{abstract}
Pollen of Litchi chinensis (Litchi) is a major aeroallergen of Bangladesh. Pollen of this fruits plant was collected from full bloomed flower growing in different places of Rajshahi in Bangladesh. Pollen protein was extracted and partial purified by means of long-term PBS extraction, salting out, dialysis, gel filtrations and DEAE-Cellulose chromatography and the protein was designated as LFPP (Litchi flowers pollen protein). Gel filtration of the purified pollen protein gives two main peaks. The major peak gives four bands on SDS-PAGE. The enzyme (pectate lyase) proteins after gel filtration again re-purified by Ion exchange chromatography, a single band in the protein profile of LFPP, (M.W. 28kDa) was the major allergenic component of Litchi chinensis (Litchi) flower pollen. The homogeneity and the molecular weight of the protein were estimated by SDS-PAGE, and Gel filtration was $28 \mathrm{kDa}$. The allergenic protein was identified by skin prick tests and showed the pectate lyase (Pel) activity. Skin-prick tests also revealed highest degree of sensitivity to the Nawabgang sample giving positive response in $80 \%$ of the patients. Skin reactivity ranged between $1^{+}$and $3^{+}$.
\end{abstract}

KEYWORDS: Pollen, Allergen characterization; Litchi chinensis, Skin-prick tests.

\section{Introduction}

It is well known that there has been a gradual increase in the number of people suffering from allergy and other respiratory diseases. About $15-20 \%$ of the world's populations are suffering from allergic disorders i.e. allergic rhinitis, bronchial asthma, atopic dermatitis and urticaria (Singh et al. 1994). According to a survey by Kjellman (1993), one child out of every three, has a history of allergy or atopic disease before reaching the age of seven to ten years. Among the various aeroallergens, the role of pollen in causing respiratory disorders in sensitive patients has been greatly realized (Kjellman, 1993). Pollen allergy is caused by proteins, glycoproteins or even a single peptide which are present in the pollen wall and cytoplasm (Chanda 1994). The soluble proteins have been generally proved to be responsible for causing nasobronchial allergy. Thus the detection of the site of origin, isolation and characterization of allergy causing proteins or glycoprotein is now a very challenging task for aero biologists working in the field (Cresti 1992). Pollen samples collected from different source materials, stages of inflorescence, time intervals, years, different geographical places and also periods of storage, show significant variation in their allergenic components (Singh 1993).

The role of pollen as a causative agent of respiratory allergic disorders is very well established, as is evident from the recent increase of reports from across the world (Ortega et al., 1992; Singh et al. 1994; Amato et al. 1998; Arnon et al., 1998). Consequently, it provides considerable 
variation in the quality and quantity of airborne pollen in different ecogeographic regions of the country (Singh et al., 1980; Singh 1982; Gupta et al., 1984; Nair 1986). Bangladesh is blessed with the richest delicious seasonal fruits flora, particularly northern parts of Bangladesh, blessed with famous fruits trees like mango, Litchi, banana, black berry etc. We reported earlier, mango pollen is one of the important components of airborn allergenic pollen (Talukder et al., 2012). The lychee (Litchi chinensis, and commonly called leechi, litchi, laichi, lichu, lizhi) is the sole members of the genus Litchi in the soapberry family, sapindaceae. It is a tropical and subtropical fruit tree native to China, and now cultivated in many parts of the world. The fresh fruit has a "delicate, whitish pulp" with a "perfume" flavor that is lost in canning, so the fruit is mostly eaten fresh (Davidson 2006).

According to Thommen (1931), an essential requirement for pollen to cause an allergic reaction in human beings, is that it should come from a wind pollinated plant. It is also known that the abundance of particular taxa in a particular area could be responsible for the predominance of the pollen of those taxa in the atmosphere of that region. Although studies on the allergenic properties of airborne pollen from various species have been carried out by several workers (Shivpuri et al., 1979; Singh et al. 1987; Singh et al., 1993; Mondal et al., 1997) information on allergy to aerial pollen from $L$. chinensis tree species has been completely lacking. In view of the extensive distribution of $L$. chinensis trees in the Rajshahi area and the prevalence of its pollen in the atmosphere, we decided to study the allergenic properties of its pollen with particular reference to skin prick testing (clinical test) with allergic disorders in the population of different geographic regions (villages) around Rajshahi and partially to characterize its pollen antigen properties.

\section{Materials and Methods}

\section{Source of pollen Material}

$50 \mathrm{~g}$ of pollen were collected (hung fine net under the litchi trees) separately from the forest ranges of Nawabgang, Thanor, Rajshahi Town and Rajshahi University campus litchi garden in Bangladesh during the pollination period in March to April. These pollen grains were then processed for $>95 \%$ purity by sieving through different grades of sieves (100, 200, and 300 mesh $/ \mathrm{cm}^{2}$ ). All the samples were analyzed under the microscope which revealed pollen purity (shape \& size) varying from $85 \%$ to $90 \%$. To remove lipids and irritants of low molecular mass, the pollen sample was defatted with diethyl ether by repeated changes, until the ether become colorless. The defatted pollen powder was then completely vacuum-dried and stored at $4^{0} \mathrm{C}$ in airtight containers until further use.

\section{Protein Extraction}

The defatted dried pollen powder was extracted at 1:20(w/v) in $0.2 \mathrm{M}$ Tris- $\mathrm{HCl}$ buffer, $\mathrm{pH} 7.4$ according to the method of Singh et al (1993) with slight modification (Mondal et al. 1997) by continuous stirring at $4^{0} \mathrm{C}$ for 24 hours using magnetic stirrer. The extract was clarified by centrifugation at $15,000 \mathrm{x}$ g for $20 \mathrm{~min}$ at $4^{0} \mathrm{C}$. The supernatant was collected and was subjected to fractional precipitation by solid ammonium sulphate. It was made up to $80 \%$ saturation by slow addition of the salt and was stored for 4 hours at $4^{0} \mathrm{C}$ in a freezer. After centrifugation the precipitate was re-suspended in $0.2 \mathrm{M}$ Tris- $\mathrm{HCl}$ buffer, $\mathrm{pH} 7.4$ and desalted by dialyzing against 
distilled water for $48 \mathrm{hrs}$ at $4-10^{\circ} \mathrm{C}$ by frequent changes of the water using dialysis sacs (MW cut off $9 \mathrm{kDa})$. Finally the supernatant was passed through a Millipore filter membrane $(0.45 \mu \mathrm{m})$, lyophilized in small aliquots, and stored at $-20^{\circ} \mathrm{C}$ until further use.

\section{Purification of Litchi Flowers Pollen Protein (LFPP)}

Gel Filtration Chromatography: The crude protein solution $(100 \mathrm{mg} / 5 \mathrm{ml})$ was applied to the column $(1.5 \times 29.0 \mathrm{~cm})$ of Sephadex-G 75 (Uppsala, Sweden) and was pre-equilibrated with 50 $\mathrm{mM}$ phosphate buffer, $\mathrm{pH} 7.2-7.4$, at $4^{\circ} \mathrm{C}$. The column was eluted with the same buffer at a flow rate of $25 \mathrm{ml} / \mathrm{h}$ and each $2.5 \mathrm{ml}$ fractions were collected. The absorbance of the column effluent was monitored at $280 \mathrm{~nm}$ using an Auto UV-Visible sprectophotometer, UV-280, Japan. Figure1 shows the purification pattern of pollen protein by gel chromatography.

Ion Exchange Chromatography on DEAE cellulose: A column $(2.0 \mathrm{X} 26.0 \mathrm{~cm})$ of DEAE-

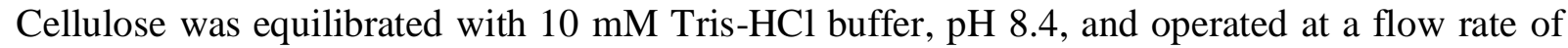
$25 \mathrm{ml} / \mathrm{h}$. After gel filtration protein from peak F-2 (fraction no. 21-35) combines together and reduces its volume to $5 \mathrm{ml}$ by freeze drying. Gel filtration protein fractions ( $5 \mathrm{ml}$ volume) containing Pectate lyase activity (around 60mg) were applied to the ion exchange column and washed by about $100 \mathrm{ml}$ of $10 \mathrm{mM}$ Tris- $\mathrm{HCl}$ buffer. Enzyme protein was eluted with $0.2 \mathrm{M} \mathrm{NaCl}$ in $10 \mathrm{mM}$ Tris- $\mathrm{HCl}$ buffer $\mathrm{pH}$ 8.3. Following ion-exchange chromatography, the combined enzyme active fractions (Fig-2, fraction no. 25-30) were stored in $50 \%(\mathrm{v} / \mathrm{v})$ glycerol at $-20^{\circ} \mathrm{C}$. Glycerol was removed by dialysis against Tris-HCl buffer before this enzyme solution is used for further enzyme assay, skin prick test and other allergen research studies.

\section{Pectate Lyase (Pel) Activity Assays:}

The activity of pectate lyase (Pel)-LFPP was determined by monitoring the absorbance increase at $232 \mathrm{~nm}$ of a $1-\mathrm{ml}$ reaction mixture containing sodium polypectate at $22^{\circ} \mathrm{C}$. To start the reaction, $5 \mu \mathrm{l}$ of appropriately diluted protein were mixed with $870 \mu \mathrm{l}$ of $50 \mathrm{mM}$ Bis-Trispropane (BTP), $\mathrm{pH} 9.5$, containing the optimal $\mathrm{CaCl}_{2}$ concentration and $125 \mu \mathrm{l}$ of $1 \%$ sodium polypectate. [For preparation of stock solutions of $1 \%$ sodium polypectate, polygalacturonic acid (85-90\% purity, Sigma) was dissolved in deionized water, boiled for 5 minutes, and centrifuged at $10,000 \times \mathrm{g}$ for 10 minutes to remove sedimented materials. $50 \mathrm{mM} \mathrm{BTP}, \mathrm{pH} 9.5$, containing the optimal $\mathrm{CaCl}_{2}$ concentration was prepared just prior to assays.] One unit of pectate lyase activity was defined as described (Wellhausen et al,. 1996). $1 \mu \mathrm{mol}$ of unsaturated product formed $/ \mathrm{min}$, which equaled 1.73 absorbance unit's $\min ^{-1}$ and the specific activity, was expressed as unit's mg${ }^{1}$ protein. Protein concentration was determined by the method of Bradford (Bradford, 1976).

\section{Estimation of Protein}

The protein concentrations in the crude extract, as well as in the various eluted enzymatically active fractions, was estimated by the method of Lowry et al. (1951) with a slight modification, as the protein was precipitated with phosphotungestic acid and then dissolved in $2 \%$ sodium hydroxide. The experiment was repeated five times within $10 \%$ variability, and the mean value was taken for protein concentration. A calibrated solution of lipid-free bovine serum albumin (BSA) was used as a standard.

Protein Gel Electrophoresis 
The protein sample was heated with an equal amount of sample buffer $[0.06 \mathrm{M}$ Tris $\mathrm{HCl}(\mathrm{pH}$ 6.8), $1 \%$ SDS, $10 \%$ sucrose, $0.5 \% \beta$-mercaptoethanol, $0.01 \%$ Bromophenol blue] at $100^{\circ} \mathrm{C}$ for 3 min. $10 \mu \mathrm{l}$ of the sample containing $85 \mu \mathrm{g}$ of protein was loaded in the well of a $12 \% \mathrm{~T}$ mini-gel (8 $\times 7 \mathrm{~cm}$ gel) Mini-Protean II slab gel apparatus (Bio-Rad, Hercules, CA, USA) and the gel was run using the method of Laemmli (1971) [0.05M Tris, 0.192 M Glycine, 0.1\% SDS, pH 8.4] at room temperature for 2 hours $30 \mathrm{~min}$, at $70 \mathrm{~V}$. The molecular mass of the fractions was calculated by calibrating with standard marker protein, lysozyme $(14 \mathrm{kDa})$, trypsin inhibitor (20 $\mathrm{kDa})$, carbonic anhydrase (29 kDa), ovalbumin (45 kDa), albumin (BSA, $67 \mathrm{kDa})$ [Pharmacia, Uppsala, Sweden]. After electrophoresis, the gel was stained with $0.1 \%$ coomassie brilliant blue R-250 and destained with methanol: acetic acid:water (4:1:5) mixture for 12 hours.

\section{Recovery protein from gel}

Protein was eluted from the gel following the method of Wilson and Goulding (1986). After electrophoresis, one side of the gel (covering 2 lines) was cut vertically and stained to ascertain the banding positions and only those portions corresponding to the protein bands to be recovered were cut out from the other half of the unstained gel. The gel pieces were transferred to pretreated dialysis bags filled with electroelution buffer (containing 0.05M Tris and 0.192M Glycine, $\mathrm{pH}$ 8.4). These dialysis bags were immersed in the electrophoresis tank of a horizontal gel apparatus containing the same buffer and electroelution was carried out for $3 \mathrm{~h}$ by passing electric current (120V) through the bags. At the end, the current was reversed for 30seconds in order to release the protein from the wall of the sacs. The buffer containing the eluted proteins were then transferred through a cotton plugged Eppendrof tube and centrifuged for 2 min to remove contaminating gel particles. The protein in each fraction was quantified and each fraction was again electrophoresed to check its homogeneity.

\section{Skin Prick Test}

The skin tests were performed on patients suffering from nasobronchial allergy as well as healthy volunteers (120 no. healthy volunteers for 4 different location allergen protein skin tests and 50 no. nasobronchial patients, age between $9-60$ years; male \& female for purified litchi allergen protein) at Rajshahi University Medical center and Rajshahi Medical Collage Hospital, Bangladesh. Each patient was tested by placing $10 \mu 1$ of each allergen; at least $5 \mathrm{~cm}$ apart on the volar surface of his/ her forearm and each site was then pricked with a disposable hypodermic needle. Negative and positive controls were also performed. The negative control solution used was the buffer saline in which the allergen was resuspended and the positive control solution was histamine acid phosphate injection diluted with buffered saline to $1: 10,000$ ie $1 \mu \mathrm{g}$ of histamine acid phosphate. The patients were prohibited from using antihistamine, steroid and ephedrine for $48 \mathrm{hrs}$ before the skin prick tests. The skin reactions were read after 15 to $20 \mathrm{~min}$ from the commencement of the test. The test was quantified on the basis of the wheel diameter and graded $1^{+}$to $3^{+}$.

\section{Results and discussion}


The protein, extracted from the litchi (Litchi chinensis ) flowers pollen was partially purified by $80 \%$ ammonium sulphate salt precipitation and then followed by gel filtration and Ion exchange chromatography and was designated by (LFPP). The protein content and the profile of the pollen allergenic protein of Litchi flower collected from different region (Table-1) showed considerable variation. The concentration of protein varied between 7.6 to $9.2 \mathrm{mg} 50 \mathrm{~g}^{-1}$ with the highest concentration observed in the sample collected from Nawabgang town (Table 1). After ion exchange chromatography (Fig-2), two protein peaks were observed at fraction No. 21-35 and fraction. No.54-56. the protein, extracted from the litchi flowers showed pectinolytic activity (Pel) as evidenced in pollen from Japanese cedar in vitro test (Taniguchi et al., 1995). Pectate lyases active peak F-2a (fractions no. 25-30) was collected and stored at $-80^{\circ} \mathrm{C}$ (Taitec-VD-800F Freeze Dryer, Japan) for skin tests and other allergenic research works.

The molecular weight of litchi flower pollen protein (LFPP) was estimated by Sephadex G-75 filtration and by sodium dodecyl sulfate polyacrylamide slab gel electrophoresis (SDS-PAGE) $28 \mathrm{kDa}$ (Fig. 3). Salvatore et al., (1984) purified allergen protein from Parietaria judaica pollen showed molecular weight of $10.4 \mathrm{kDa}$ by HPLC on SDS-PAGE. The SDS-PAGE protein profiles revealed 3 bands (Fig-3) which were designated as $\mathrm{IF}_{1}$ to $\mathrm{IF}_{3}$. These bands were present in the molecular weight range of $26 \mathrm{kDa}\left(\mathrm{IF}_{1}\right) ; 28 \mathrm{kDa}\left(\mathrm{IF}_{2}\right)$ and $67 \mathrm{kDa}\left(\mathrm{IF}_{3}\right)$ after gel filtration. Among them, only one band $\left(28 \mathrm{kDa}, \mathrm{IF}_{2}\right)$ is enzymatically (pectate lyases) active, which was found after DEAE-cellulose column chromatography and also allergenic skin test positive in nature (Table$3)$.

Skin prick tests were performed with the total extract (protein purified by gel filtration) on 30 healthy volunteers and 50 patients already suffering from nasobronchial allergy (Table1I). Variation in skin sensitivity was also observed in the different samples (Table-2), as well as the various eluted fractions $\left(\mathrm{IF}_{1}\right.$ to $\left.\mathrm{IF}_{3}\right)$ of pollen sampled in different locations performed in 50 patients already suffering from respiratory allergic disorders with their ages ranging between 965 years (Table-3). The highest degree $\left(3^{+}\right)$of skin reactivity was observed in the case of the Nawabgang town sample with 28 patients $(93 \%)$ showing positive reactions, of whom 4 patients $(13.3 \%)$ showed $1^{+}$reaction, 6 patients $(20 \%)$ showed $2^{+}$reactions, while $3^{+}$reactions was obtained in 18 patients $(60 \%)$. The lowest degree $\left(1^{+}\right)$of skin reactivity was observed in case of the Rajshahi University campus sample with 21 patients (70\%) reacting positively and only 3 person $(10 \%)$ showing $3^{+}$reaction. The pollen of Litchi flower proves to be one of the aeroallergens of Rajshahi Regions capable of inducing respiratory allergic diseases in Bangladesh. A new allergen protein M.W $27 \mathrm{kDa}$, from mango pollen, collected from Rajshahi zone has been reported earlier (Talukder et al., 2012). The differences in the protein profiles, as well as the protein content in the Litchi flower pollen samples collected from the various locations of Rajshahi, likely to be associated with variable climatic conditions prevailing in these areas and soil conditions, as has been earlier suggested by Singh et al. (1993). The highest rate of skin sensitivity in the sample collected from Nawabgang town may be due to the higher protein content as well as the additional allergenic components, resulting in sensitivity to some patients due to these proteins fractions. Another factor for increasing the allergenicity of pollen is air pollution. This is effected by changing the kind and proportions of exinic mineral elements, which was reported earlier by (Newmark et al., 1967; Amato et al. 1998) or by affecting pollen morphology or protein profile (Shivpuri et al., 1979; Arnon et al., 1998). Thus, the highest air- 
allergenic atmosphere of Nawabjang town, being the most polluted due to bricks making industries, rice mills, pulp \& paper industry, Jute mills (industrialization) and dust particle carried by wind, may be responsible for the increased rate of allergenicity of the pollen grains.

\section{Conclusion}

The present study reveals that litchi flower pollen is capable of inducing hypersensitivity is one of the aeroallergens and should be considered to be a cause of respiratory allergic causes in Bangladesh. Skin tests are the major diagnostic tool for allergy and reveal the pollen of litchi to be a potent allergenic offender. Out of three proteins $\mathrm{IF}_{1}, \mathrm{IF}_{2}, \mathrm{IF}_{3}$ only $\mathrm{IF}_{2}(28 \mathrm{KDa}$ ) showed positive response in all the 50 patients with total pollen extract, can thus be said to be the major allergenic band $28 \mathrm{kDa}$ being other minor contributors. Pollen extracts contain complex mixtures of proteins, complex carbohydrates, lipids, enzymes, lectins etc (Mondal \& Mondal, 1997, Mondal et al. 1997 a, b, 1998; Parui \& Mondal 1998, Parui et al. 1998, 1999) and the crude antigenic extracts usually contain several other components other than the proteins to which the patients may show some allergic reaction. The method followed in this investigation enable us to isolate particular protein bands from a mixture of total proteins and to test with present day knowledge of epitope mapping and molecular cloning, the present study will contribute to the design of immunotherapic vaccines and the production of unlimited quantities of defined allergens. This approach of isolating particular proteins from a mixture of total proteins for the detection of allergenic proteins is reported here for the first time.

\section{References}

Amato D., Spieksma FTh M., Liccardi G, (1998). Pollen-related allergy in Europe. Allergy. 53: 567-578.

Arnon G., Chohen R.C., Yoav W. (1998). Allergic response to pollen of ornamental plants: high incidence in general atopic population and especially among flower growers. J. Allergy Clin Immunol. 102: 210-214.

Bradford MM. (1976). A rapid and sensitive for the quantitative of microgram quantities of protein utilizing the principle of protein-dye binding. Anal Biochem 72:248-254.

Chanda, S. (1994). Pollen Grains as Aeroallergens: Morphological, Biological and Chemical Approach. In: Agashe SN (Ed): Recent Trends in Aerobiology, Allergy and Immunology, p-85-92. Oxford \& IBH publ Co. Pvt. Itd, New Delhi.

Cresti M, Tiezzi A (Rd): (1992). Sexual Plant Reproduction, p-203-217. Springer Verlag Berlin.

Davidson, Jane L.; Davidson, Alan; Saberi, Helen; Jaine, Tom. (2006). The Oxford companion to food., 467

Gupta S. and Chanda S. (1984). Aeropalynological survey in subtropical eastern Himalayas, Kurseong. Grana. 28: 219-221.

G. Talukdar, I. Hossain, Nitai C. Roy, N. K. Sana, S. R. Kabir, K. K. Biswas, N. Roy and Ranajit Kumar Shaha.,(2012). Allergen Protein from Mango (Mangifera indica) Flowers Pollen. AsPac J. Mol. Biol. Biotechnology. Vol.20(1):11-18.

Kjellman NIM: (1993). Prediction and prevention of allergy in infants and children. Allergy Clin Immunol News, 5:131-134. 
Lowry, O.H., Roseborough, N. J., Farr, A.L., and Randall, R.J. (1951). Protein measurement with the Folin phenol reagent. J. boil. Chem. 193: 265-273.

Laemmli, U.K. (1970). Clavage of structural proteins during the assembly of the head of bacteriophages T4. Nature. 277:680-685.

Mondal, A.K. \& Mandal, S. (1997). Biochemical and clinical studies of Ailanthus excels Roxb. Pollen with reference to its dispersal.- Bangladesh J. Bot. 26(2): 115-120.

Mondal A.K., Parui S., Biswas S.R. and Mondal S. (1997a). Identification of the allergenic proteins of Ipomea fistulosa pollen- partial characterization and sensitivity test. Grana. 36:301-305.

Mondal A.K., Parui S., and Mondal S. (1997b). Aerobiology and some chemical parameters of the pollen of a few members of imosaceae in Burdwan District, West Bengal. -Res. J. Chem. Environ. 1: 12-19.

Mondal A.K., Parui S., and Mondal S. (1998). Biochemical analysis of four species of Cassia L. pollen.- Aerobiologia 14: 45-50

Nair P.K.K., Joshi A.P., and Gangal S.V. (1986). Airborn pollen spores and other plant materials of India- a survey. Lucknow: CSIR Centre for Biochemicals, Delhi and NBRI.

Newmark F.M. and Itkin I.H. (1967). Asthma due to pine pollen. J Allergy; 25:251-252.

Ortega G, Mortnez P.J., Martiniz H., Palacios R., Belmonte J, Richart C. (1992). Mercularis annua pollen:a new source of allergy sensitization and respiratory disease. J. Allergy Clin Immunol. 89: 987-993.

Parui, S. \& Mandal, S. (1998). Biochemical analysis and skin sensitivity test of the allergenic pollen of Datura metel L. Curr. Sci. 74(1): 66-68.

Parui, S. Mondal, A.K. \& Mandal, S. (1998). Biochemical analysis and skin sensitivity test of the allergenic pollen of Ricinus communis L. Environment \& ecology. 16(1): 40-43.

Parui, S. Mondal, A.K. \& Mandal, S. (1999). Identification and partial characterization of the allergenic proteins of Ricinus communis L.pollen- a new approach. -Grana 38(5): 311315.

Singh A.B. and Singh A. (1994). Pollen allergy- a global scenario. In Agashe S.N., editor. Recent trends in aerobiology and immunology. Oxford: IBH, 143-173.

Singh A.B. and Babu C.R. (1980). Studies on pollen allergy in Delhi: diurnal periodicityof common allergenic pollen. Allergy. 35: 311-317.

Singh A.B. and Babu C.R. (1982). Studies of atmospheric pollen allergens in Delhi: Seasonal periodicity. Ann Allergy. 48: 115-122.

Shivpuri D.N., Singh A.B., Babu C.R. (1979). New allergenic pollens of Delhi state, India and their clinical significance. Ann Allergy. 42: 49-52.

Singh A.B. (1987). Airborne pollen types of allergenic significance in India. Adv Aerobiol (Experientia Suppl). 51: 61-64.

Singh A.B., Malik P., Parkash D. and Gangal S.V. (1993). Identification of specific IgE binding proteins in castor bean (Ricinus communis) pollen obtained from different source materials. Grana. 31: 376-380.

Taniguchi, Y., Ono, A. Sawtani, M., Nanba, M., Kohno, K., Usui, M., Kurimoto, M., and Matsuhasi, T. (1995). Allergy.50: 90-93.

Thommen, A. (1931). Hayfever,--In: Asthma and Hayfever in Theory and Practice (ed. A.A.F.Coca et al. ), p 851. Thomas Publs Springfield, IL. 
Wellhausen, A.; Schöning, B.; Petersen, A.; Vieths, S. (1996). IgE-binding to a new crossreactive structure: a $35 \mathrm{kDa}$ protein in birch pollen, exotic fruit, and other plant foods. Zeitschr. Ernährungswiss. 35:348-355.

Wilson, K. \& Goulding, K.H., (1986). A Biologist's guide to principles and Techniques of Practical Biochemistry. E. Arnold Ltd, London.

\section{Table 1:}

Protein content of pollen extracts of Litchi flower from different location at Rajshahi District in Bangladesh.

\begin{tabular}{|l|l|}
\hline Place of Collection & $\begin{array}{l}\text { Protein (mg/50g of dry } \\
\text { litchi pollen) }\end{array}$ \\
\hline Nawabgang Sadder & 9.2 \\
\hline Thanor Sadder & 8.4 \\
\hline Rajshahi University & 7.6 \\
\hline Rajshahi Town & 8.6 \\
\hline
\end{tabular}

\section{Table 2:}

Results of skin tests with the active protein of Litchi flower pollen from different location at Rajshahi Division in Bangladesh.

\begin{tabular}{llllll}
\hline Place of Collection & $\begin{array}{l}\text { Total number of } \\
\text { Test persons }\end{array}$ & Negative & $1^{+}$ & $2^{+}$ & $3^{+}$ \\
\hline Nawabgang sadder & 30 & $2(6.7 \%)$ & $4(13.3 \%)$ & $18(60 \%)$ & $6(20 \%)$ \\
Thanor Sadder & 30 & $12(40 \%)$ & $9(30 \%)$ & $6(20 \%)$ & $3(10 \%)$ \\
Rajshahi University & 30 & $11(36.7 \%)$ & $9(30 \%)$ & $7(23.3 \%)$ & $3(10 \%)$ \\
Rajshahi Town & 30 & $9(30 \%)$ & $11(36.7 \%)$ & $5(16.7 \%)$ & $5(16.6 \%)$ \\
\hline
\end{tabular}


Table 3:

Result of skin tests against purified protein after gel filtration and individual antigenic (electrophoresis band proteins fraction) of litchi pollen sensitive patients.

\begin{tabular}{ccccccc}
\hline No. of Patients & Ages (yrs) & Sex & $\begin{array}{c}\text { Total } \\
\text { Protein }\end{array}$ & $\mathrm{IF}_{1}$ & $\mathrm{IF}_{2}$ & $\mathrm{IF}_{3}$ \\
\hline 5 & $09-12$ & $\mathrm{~F}$ & $2^{+}$ & $-\mathrm{ve}$ & $3^{+}$ & $1^{+}$ \\
8 & $21-27$ & $\mathrm{~F}$ & $1^{+}$ & $1^{+}$ & $3^{+}$ & $-\mathrm{ve}$ \\
5 & $50-60$ & $\mathrm{~F}$ & $3^{+}$ & $1^{+}$ & $3^{+}$ & $-\mathrm{ve}$ \\
6 & $31-45$ & $\mathrm{M}$ & $2^{+}$ & $-\mathrm{ve}$ & $3^{+}$ & $-\mathrm{ve}$ \\
12 & 55 & $\mathrm{M}$ & $3^{+}$ & $1+$ & $2^{+}$ & $1^{+}$ \\
14 & $20-26$ & $\mathrm{M}$ & $2^{+}$ & $-\mathrm{ve}$ & $3^{+}$ & $-\mathrm{ve}$ \\
\hline
\end{tabular}

Diameter of erythema $(\mathrm{mm})$ : 0 : no reaction; $1-5 \mathrm{~mm}: 1^{+} ; 6-10 \mathrm{~mm}: 2^{+} ; 11-15 \mathrm{~mm}: 3^{+}$(Total protein $=$ purified protein from gel filtration and $\mathrm{IF}=$ Electrophoresis band fraction proteins).

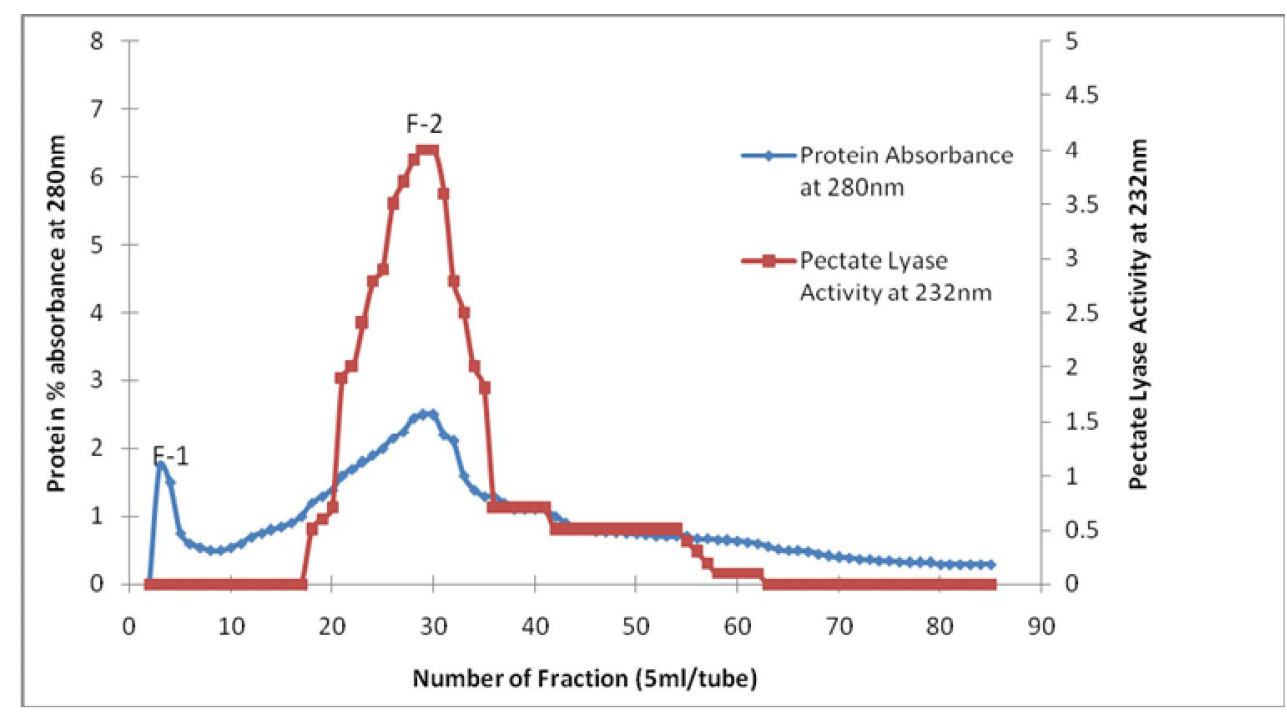

Fig.1: Gel Filtration of $40 \%$ ammonium sulphate saturated crude extract on Sephadex G-75. The crude protein solution $(100 \mathrm{mg})$ was supplied to the column $(1.0 \mathrm{x} 29.0 \mathrm{~cm})$ pre-equilibrated with $50 \mathrm{mM}$ phosphate buffer, $\mathrm{pH}$ 7.2-7.4, at $4^{0} \mathrm{C}$ and developed with the same buffer. Flow rate: $25 \mathrm{ml} / \mathrm{hour}$. 


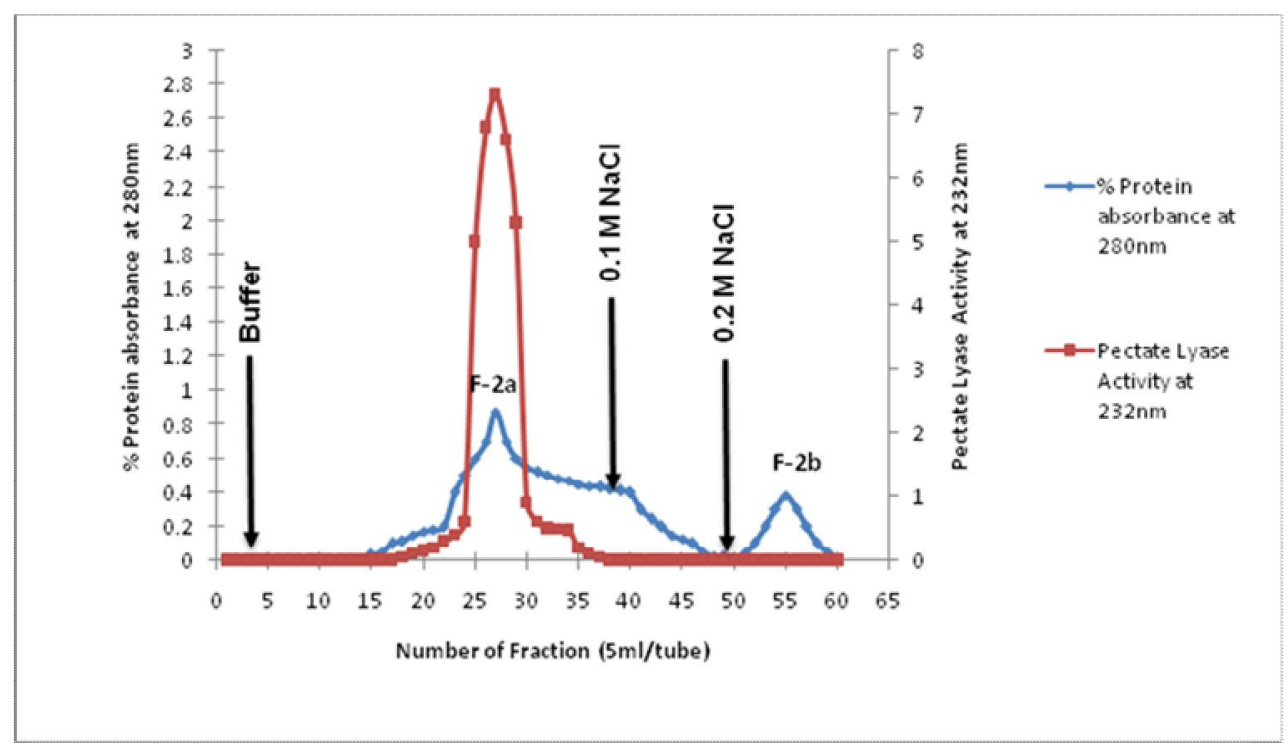

Fig. 2: Ion exchange chromatography of F-2 fraction $(60 \mathrm{mg})$ on DEAE cellulose, obtain by gel filtration, was applied to the column $(1.0 \times 26.0 \mathrm{~cm})$ pre-washed with $10 \mathrm{mM}$ Tris- $\mathrm{HCl}$ buffer, $\mathrm{pH} 8.4$, at $4^{0} \mathrm{C}$ and eluted by stepwise increase of $\mathrm{NaCl}$ concentration in the same buffer. Flow rate: 25 $\mathrm{ml} /$ hour.

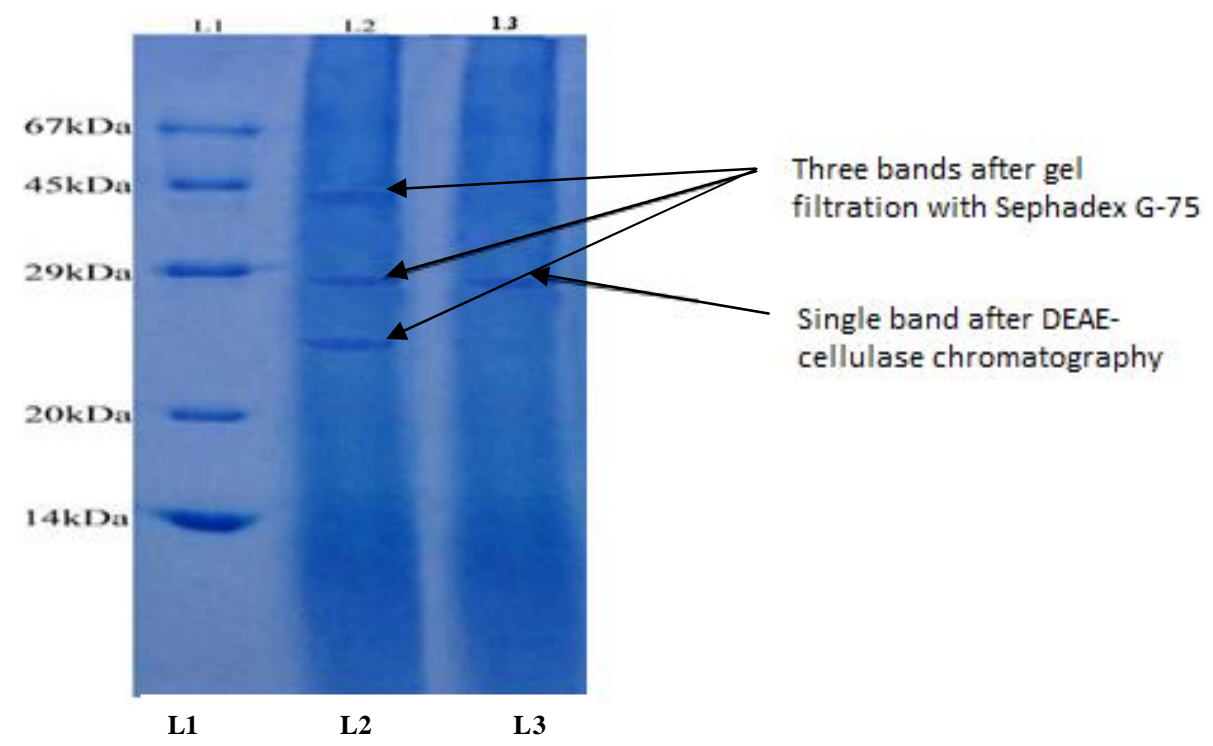

Fig3.Photographic representation of sodium dodecyl sulfate polyacrylamide slab gel electrophoretic pattern of the purified protein. L-1: Marker protein solution containing lysozyme (14 kDa), trypsin inhibitor (20 kDa), carbonic anhydrase (29 kDa), ovalbumin (45 kDa), albumin (BSA, 67kDa). L-2: Fraction from gel filtration column. L-3: Fraction from DEAE-Cellulose column. (Line-1.1: marker proteins, line-1.2: proteins after gel filtration and line-1.3: purified protein after DEAE chromatogram). 


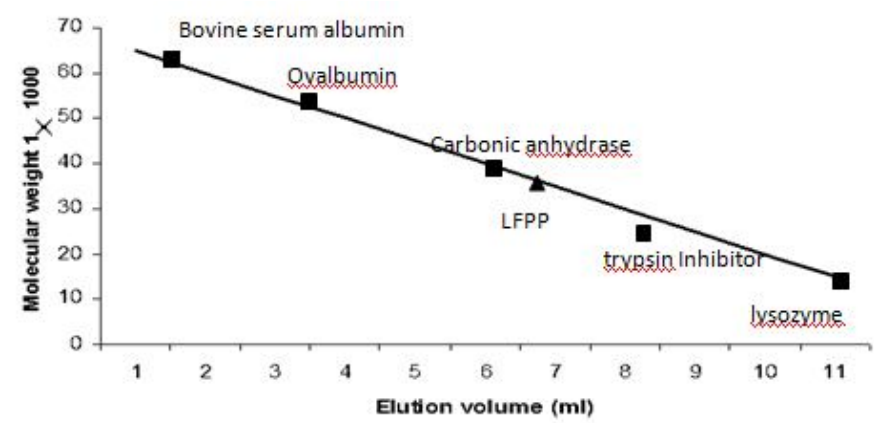

Fig.4: Molecular weight determination by gel filtration.

The molecular weight of the protein was also determined by gel filtration on Sephadex G-75 using lysozyme $(14 \mathrm{kDa})$, trypsin inhibitor $(20 \mathrm{kDa})$, carbonic anhydrase $(29 \mathrm{kDa})$, ovalbumin $(45 \mathrm{kDa})$, albumin (BSA, $67 \mathrm{kDa})$ as standard proteins. The molecular weight was calculated from the standard curve of reference proteins, which was constructed by plotting log of molecular weight against elution volume on gel filtration (Fig.-4) and estimated to be $27 \mathrm{kDa}$ for purified LFPP. 